Zabytkoznawstwo i Konserwatorstwo XL, Toruń 2011

Dariusz Markowski, Bożena Szmelter-Fausek, Sławomir A. Kamiński

\title{
Malarstwo na szkle - badania budowy technicznej i stanu zachowania na przykładzie wybranych obrazów
}

\section{Wprowadzenie}

Termin „malarstwo na szkle” kryje w sobie wiele technik dekorowazimno" rozróżnia się m.in. technikę witrochromii, pseudowitrochromii, foliochromii, technikę eglomizowania oraz malowania na lustrze ${ }^{1}$. Poszczególne techniki łączą $\mathrm{w}$ sobie malarstwo $\mathrm{z}$ techniką pozłotniczą, wykorzystują ryciny i fotografie. Jakość i ilość obrazów na szkle tworzonych na przestrzeni wieków była zależna od dostępności szkła. W czasach świetności przemysłu szklarskiego w XVIII i XIX wieku istniała możliwość zamówienia drogich obrazów wykonanych na czystym i bezbarwnym szkle.

W XIX wieku technika malowania na szkle była najczęściej stosowana przez twórców ludowych. Polska, obok Czech, Słowacji, Rumunii i Niemiec, należy do krajów, w których do dzisiaj przetrwała największa liczba przykładów ludowego malarstwa na szkle. W Polsce najwięcej eksponatów znajduje się na Śląsku, w Małopolsce oraz na Kaszubach. Wyróżnić należy kaszubskie obrazy na szkle, znajdujące się w Muzeum w Kartuzach, które reprezentują typowo polską odmianę tej dziedziny.

Obrazy na szkle wymagają szczególnej uwagi, bowiem większość z nich eksponowanych w muzeach, a zwłaszcza tych przechowywanych

1 J. Werner, Podstawy technologii malarstwa i grafiki, Warszawa-Kraków 1985, s. 88; Wł. Ślesiński, Techniki malarskie: spoiwa organiczne, Warszawa 1984, s. $211-212$. 
w magazynach muzealnych, jest w złym stanie zachowania. Do najważniejszych zniszczeń, jakim ulegają malowidła na szkle, należy zaliczyć: pęknięcia i ubytki podobrazia szklanego, utratę adhezji warstwy malarskiej do szkła oraz ubytki warstwy malarskiej². Uszkodzeniom ulega także rama i osłona odwrocia obrazu (deski, kartony). Są to głównie zwichrowania i pęknięcia listewek, a także zarysowania i ubytki w warstwie złoceń ramy.

Celem tego artykułu jest przedstawienie budowy technicznej i stanu zachowania wybranych obrazów znajdujących się w polskich muzeach i zbiorach prywatnych oraz analiza zniszczeń i przyczyny ich powstawania.

Analizom $^{3}$ poddano sześć obrazów: Św. Mateusz z Muzeum w Kartuzach, Matka Boska Bolesna z Muzeum Etnograficznego w Toruniu, Martwa natura - Vanitas z Muzeum Okręgowego w Toruniu, Św. Wincenty à Paulo z Muzeum Diecezjalnego we Włocławku, Pejzaż i Widok Amsterdamu - kamienice ze zbiorów prywatnych. Wybrane obrazy reprezentują różne techniki malarstwa na szkle: technikę pseudowitrochromii (franc. fixé sous verre, niem. Die Englische Malerei hinter Glass), technikę lustrzaną, technikę witrochromii (franc. peinture sous verre, niem. Hinterglasmalerei), technikę eglomizowania (franc. verre églomisé, niem. Eglomisieren) oraz technikę crystoleum.

\section{Analiza budowy technicznej i stanu zachowania}

Na podstawie analizy wizualnej przebadano technikę warstwy malarskiej i sposób opracowania malarskiego, a także inne elementy wchodzące w skład budowy obrazów na szkle, jak fotografia, masa perłowa oraz obecność werniksu. Pobrano próbki z obrazu Św. Wincentyà Paulo,

2 E. Jablonski, The Conservation of Reverse Painting on Glass: a General Overview, „The Picture Restorer”, Spring 2000, s. 6.

3 Analizy wykonano w ramach pracy magisterskiej „Malarstwo na szkle - zarys historii, techniki, stan zachowania, sposoby konserwacji oraz badania właściwości i skuteczności środków do podklejania odspojonej warstwy malarskiej do szkła”, napisanej przez Bożenę Szmelter-Fausek w Zakładzie Konserwacji Malarstwa i Rzeźby Polichromowanej UMK, pod kierunkiem prof. UMK dr. hab. Dariusza Markowskiego, we współpracy z dr. Sławomirem Kamińskim, Toruń 2008. 
Pejzaż $i$ Widok Amsterdamu - kamienice, w celu zbadania spoiwa i pigmentów. Wykorzystano metody fizyczne i mikrochemiczne ${ }^{4}$. Strukturę Widoku Amsterdamu - kamienice przebadano metodą Koherentnej Tomografii Optycznej ${ }^{5}$.

W przypadku podobrazia szklanego określono jego wymiary: wysokość, szerokość i grubość, analizowano wygląd: połysk i fakturę powierzchni, występowanie pęcherzyków powietrza oraz ślady procesu i metody wytwarzania. Przeanalizowano także osłonę odwrocia i sposób oprawienia obrazu.

Rodzaje i przyczyny zniszczeń określono na podstawie wyników analizy wizualnej metodami fizycznymi - obserwacji w świetle rozproszonym, skośnym i pod mikroskopem ${ }^{6}$.

\section{Św. Mateusz}

Obraz pochodzi z drugiej połowy XIX wieku , należy do zbiorów Muzeum Kaszubskiego im. Franciszka Tredera w Kartuzach. Reprezentuje odmianę kaszubskiego ludowego malarstwa na szkle - pseudowitrochromię. Zbudowany jest z barwnej litografii podklejonej pod szkło oraz $\mathrm{z}$ malarskiej dekoracji na odwrociu szkła wykonanej w technice tłustej tempery. Rysunek został wykonany za pomocą jasnobrązowej farby laserunkowej nałożonej pędzelkiem. Następnie naniesiono odpowiednie kolory, tworzące kompozycję dekoracji obrazu. Użyto żółcieni, czerwieni, zieleni do namalowania dekoracji oraz bieli do wypełnienia tła. Farbę nakładano swobodnie. Odwrocie warstwy malarskiej zabezpieczono pokostem.

Powierzchnia szkła jest gładka i równa, jednakże zauważono minimalne pofalowania tafli. Szkło nie ma pęcherzyków powietrza i stanowi ciągłą czystą masę. Podobrazie ma wymiary 28,5 x $24,5 \mathrm{~cm}$.

4 Badania wykonano w Zakładzie Technologii i Technik Malarskich UMK.

5 Badania wykonała mgr Magdalena Iwanicka w Zakładzie Fizyki Medycznej Wydziału Fizyki i Astronomii UMK.

6 Dokonano obserwacji pod mikroskopem obrazu Widok Amsterdamu - kamienice.

7 A. Błachowski, Malarstwo na szkle, Tradycje i współczesność polskiej sztuki ludowej, t. I, Lublin-Toruń 2004, s. 151. 


\section{Stan zachowania}

Obraz jest w złym stanie zachowania, został zniszczony na skutek uderzenia. Podobrazie jest pęknięte na siedem fragmentów. Brakuje jednego elementu szkła po prawej stronie obrazu. Warstwa malarska jest odspojona. Najwięcej ubytków można zaobserwować wokół pęknięć podobrazia.

Obraz został również zniszczony w trakcie nieumiejętnie przeprowadzonej konserwacji. Podczas sklejania kawałków szkła wprowadzany środek klejący został kapilarnie podciągnięty przez warstwę malarską, wywołując w niej zmiany kolorystyczne wzdłuż pęknięć szkła. W dolnej partii obrazu cała warstwa jest przesączona klejem, co wpłynęło na dodatkowe zniszczenia w postaci odspojeń. Spoiwo użyte do klejenia szkła przeniknęło także do litografii, czego efektem są ciemne zaplamienia papieru występujące w okolicach pęknięć szkła. Zaobserwowano ciemne plamki w dolnej partii warstwy malarskiej, co wskazuje na obecność mikroorganizmów.

Obraz jest oprawiony w drewnianą ramę. Pomiędzy szkłem a ramą umieszczono osiem kawałków korka (po dwa w każdym narożniku), które dystansują obraz od felca ramy. Rama od strony odwrocia i na bocznych krawędziach jest oklejona taśmą klejącą.

\section{Matka Boska Bolesna}

Obraz pochodzi z przełomu XVIII/XIX wieku, należy do zbiorów Muzeum Etnograficznego im. Marii Znamierowskiej-Prüfferowej w Toruniu. Reprezentuje przykład śląskiego ludowego obrazu wykonanego na odwrociu szkła w technice lustrzanej.

Postać świętej i dekoracje malarskie wykonano farbami laserunkowymi, następnie całość pokryto amalgamatem (stopem rtęci i cyny), który stworzył efekt lustra.

Rysunek został wykonany za pomocą czarnej (postać i ornamenty), brązowej (opracowanie twarzy) i białej (kwiatowe dekoracje) farby nałożonej pędzelkiem. Następnie płasko naniesiono odpowiednie kolory, tworzące kompozycję dekoracji obrazu. Płaszcz i elementy dekoracyjne opracowano farbami laserunkowymi, jedynie przy karnacji zasto- 
sowano farby kryjące. Użyto żółcieni, zieleni, błękitu, brązu, czerwieni, szarości oraz bieli.

Powierzchnia szkła jest gładka i równa, nie zauważono pęcherzyków powietrza. Obraz o wymiarach 32 x $23 \mathrm{~cm}$ jest oprawiony w oryginalną drewnianą ramę.

\section{Stan zachowania}

Warstwa malarska oraz amalgamatu jest odspojona, popękana i posiada wiele ubytków. Odspojenia te przeszkadzają w odbiorze estetycznym obrazu, szczególnie w warstwie amalgamatu, która straciła lustrzane lśnienie i stała się matowa. W jej obrębie widoczne są także drobne ciemniejsze punkty świadczące o ogniskach korozji. Warstwa amalgamatu ma spękania o charakterze miseczek, których krawędzie są uniesione w stronę szkła. Najwięcej uszkodzeń jest w dolnej partii obrazu. Przyczyną niszczenia tych warstw była prawdopodobnie woda kondensacyjna spływająca po odwrociu obrazu. Z kolei tektura, która osłania odwrocie, na skutek wilgoci przykleiła się do warstwy lustrzanej i podczas wysychania w wyniku deformacji tektury, warstwa ta została oderwana od szkła. Podobrazie szklane uległo potłuczeniu.

\section{Martwa natura - Vanitas ${ }^{*}$}

Obraz pochodzi z pierwszej połowy XIX wieku. Należy do zbiorów Muzeum Okręgowego w Toruniu. Reprezentuje technikę witrochromii z elementami eglomizowania. Obraz namalowano na odwrociu szkła w technice olejnej „na zimno”. Niektóre elementy kompozycyjne obrazu opracowano w technice eglomizowania, z zastosowaniem folii pozłotniczej żółtej - mosiężnej (stop miedzi i cynku) oraz białej - srebrnej, kła-

* Informacje dotyczące datowania i budowy technicznej obrazu pochodzą z: R. Szalonek, „Malarstwo na szkle na przykładzie obrazu Martwa natura - Vanitas, I poł. XIX w. Badania materiałów i rekonstrukcja wybranych technik pozłotniczych i malarskich", praca magisterska napisana pod kierunkiem prof. dr. Zb. Brochwicza i mgr E. Mirowskiej w Zakładzie Technologii i Technik Malarskich UMK, Toruń 1988; idem, „Dokumentacja prac konserwatorsko-restauratorskich obrazu Martwa natura - Vanitas na szkle", praca pod kierunkiem dr Bogumiły Rouby, Zakład Konserwacji Malarstwa i Rzeźby Polichromowanej UMK, Toruń 1988, nr dok. 625. 
dzionej na wytrawę olejną. Do folii srebrnej zastosowano żółtobrązowy lakier pozłotniczy. Płatki metalu nałożono na modelunek wykonany farbami laserunkowymi.

Rysunek wykonano za pomocą ciemnobrązowej farby, nakładanej pędzelkiem. Następnie opracowano warstwy barwne obrazu. Plamy barwne nakładano cienko, gładko i akwarelowo. Bardziej kryjącymi farbami namalowano jedynie marmurowy postument o dość wyraźnym światłocieniu, czaszkę oraz ciemne płaskie tło. Na koniec naklejono srebrną folię pozłotniczą (w obrębie tkaniny, świecznika, wazy, księgi, naczynia z bańkami mydlanymi i smugi dymu). Na odwrociu, poza miejscami z folią, założono prawie jednolitą szarą warstwę malarską, niewidoczną od lica. Ostatnim etapem pracy było nałożenie mosiężnej folii na brzegach obrazu, od strony lica.

Zastosowane pigmenty to biel ołowiana, żółcień organiczna, czerwień organiczna, miedzianka, umbra, czerń węglowa.

Podobrazie szklane o wymiarach $26,5 \times 21,6 \mathrm{~cm}$ jest bardzo cienkie, przezroczyste o nieznacznie niebieskawozielonym zabarwieniu. Brzegi szyby są nierówno obcięte i wyszczerbione. W szkle występują pęcherzyki o zróżnicowanej wielkości, rozmieszczone w całej masie. Powierzchnia szkła jest nierówna, „falująca”.

Obraz jest zabezpieczony drewnianą deseczką i oprawiony w drewnianą ramę profilowaną, pomalowaną czarną farbą.

\section{Stan zachowania}

Obecny stan zachowania obrazu jest dobry. Warstwa malarska ma dobrą adhezję do szkła. Miejscami w oryginalnej warstwie malarskiej widoczne są niewielkie pęcherzyki powietrza.

Uzupełnienia ubytków warstwy malarskiej z 1988 i 1990 roku w wyniku upływu czasu minimalnie zmieniły odcień, są ciemniejsze od oryginalnej barwy poszczególnych partii warstwy malarskiej.

\section{Dane o konserwacji}

Podczas prac konserwatorskich w 1988 roku do podklejenia warstwy malarskiej do szkła zastosowano żywicę akrylową - Osolan K będącą polimerem metakrylanu metylu z metakrylanem butylu. Do uzupełnienia 
warstw laserunkowych użyto farb akwarelowych, natomiast do rekonstrukcji warstwkryjących - tempery. Farbybyły rozcieńczane wodą destylowaną z dodatkiem żółci wołowej. Do uzupełnienia ubytków srebra użyto srebrnej folii nakładanej na białko jaja rozcieńczone wodą destylowaną 1:1. Po wyschnięciu folię srebrną zabezpieczono od odwrocia werniksem damarowym przygotowanym $\mathrm{z}$ damary rozpuszczonej w olejku terpentynowym w stosunku objętościowym 3:1. Ubytki folii mosiężnej z obramowania uzupełniono brązą rozcieńczaną olejkiem terpentynowym.

W 1990 roku z uwagi na odspajanie się punktowań akwarelowych od warstwy Osolanu K, wymieniono je na punktowania w technice olejnej.

\section{Św. Wincenty à Paulo}

Obraz z XVIII wieku (?) ${ }^{8}$ pochodzi z Muzeum Diecezjalnego we Włocławku. Namalowany został na odwrociu szkła w technice witrochromii za pomocą farb olejnym. Powierzchnię szkła przeklejono klejem, następnie przystąpiono do opracowywania kompozycji obrazu. Plamy barwne nakładano kryjąco, swobodnie zaczynając od świateł w kierunku cieni i kolorów lokalnych. Na odwrociu obrazu zaznaczają się impastowe dukty pędzla oraz cząstki grubo zmielonego pigmentu. $\mathrm{Na}$ koniec nałożono na odwrocie żywiczną warstwę zabezpieczającą. Zastosowane pigmenty to biel ołowiana, żółcień, czerwień, błękit pruski, umbra naturalna, czerń roślinna9 ${ }^{9}$

Podobrazie szklane o wymiarach 42,8 x 32,1 x 0,4 cm jest przezroczyste o równej powierzchni. Brzegi szyby są nierówno obcięte i wyszczerbione. Osłonę odwrocia obrazu pełni czarny woskowany papier, który nadaje głębię i nasyca tony kolorystyczne obrazu, oraz tektura. Obraz jest oprawiony w ozdobną złoconą ramę.

\section{Stan zachowania}

Stan zachowania obrazu jest dobry. Warstwa malarska ma dobrą adhezję do szkła. Jedynie przy krawędziach są widoczne ubytki w warstwie

8 Katalog Zabytków Sztuki w Polsce, red. T. Chrzanowski, M. Kornecki, t. XI, Warszawa 1988, s. 59.

9 Pobrano próbki z obrazu z partii tła (jasny błękit) oraz z habitu (czerń). 
malarskiej oraz miejscami w obrębie czarnego habitu. Na powierzchni czarnego papieru zabezpieczającego warstwę malarską zaobserwowano białe punkty, które prawdopodobnie świadczą o mikroorganizmach.

\section{Pejzaż $\dot{z}^{\star}$}

Obraz z XIX wieku (?), pochodzi za zbiorów prywatnych. Namalowany został na odwrociu szkła w technice witrochromii za pomocą farb olejnych $^{10}$. Farbę nakładano kryjąco i swobodnie. Na odwrociu widoczny jest dukt pędzla. Do namalowania obrazu użyto bieli, żółcieni, błękitu, zieleni i brązu.

Szkłoowymiarach 20,5x27 cm (zramą)igrubości $0,12 \mathrm{~cm}$ jest płaskie i o równej płaszczyźnie. Odwrocie obrazu jest osłonięte dwiema tekturami, z których zewnętrzna została przyklejona do ramy. Obraz jest oprawiony w oryginalną drewnianą ramę złoconą płatkami złota na pulment.

\section{Stan zachowania}

Obraz jest w złym stanie zachowania. Warstwa malarska jest odspojona od szkła i ma wiele ubytków. Znajdujący się na odwrociu papier, mający pełnić funkcję warstwy zabezpieczającej obraz, przyczynił się do poważnych zniszczeń w obrazie. Ponieważ był umieszczony zbyt blisko warstwy malarskiej, w momencie dużych zmian wilgotności względnej powietrza, papier pochłaniał wilgoć oraz wodę kondensacyjną z odwrocia obrazu, deformował się i jednocześnie konsolidował z warstwami barwnymi. Gdy następował spadek wilgotności, podczas wysychania, kurczył się i jednocześnie odrywał warstwę malarską od szkła na zasadzie techniki strappo. Kolejne niesprzyjające warunki wilgotnościowe przyczyniały się do kolejnych naprężeń i głębszych deformacji papieru, w wyniku czego oderwana warstwa malarska ulegała przesunięciom. Warstwa malarska, która została oderwana od szkła, miała za słabą adhezję do jego powierzchni, prawdopodobnie z braku dostatecznego przeklejenia.

* Nr inw. Zakładu Konserwacji Malarstwa i Rzeźby Polichromowanej UMK -1388 .

10 Spoiwo określono na podstawie badań mikrochemicznych. 
Podobrazie jest pęknięte na sześć części. Po prawej stronie obrazu brakuje jednego fragmentu szkła, który odpadł wraz z warstwą malarską. Zewnętrzna warstwa tektury osłaniającej tył obrazu jest zniszczona, zakwaszona, krucha i ma poszarpane krawędzie. Powierzchnia złoceń ramy jest porysowana.

\section{Widok Amsterdamu - kamienice}

Obraz powstał w latach 1880-1910 ${ }^{11}$. Pochodzi ze zbiorów prywatnych. Wykonanyzostałw technicecrystoleum ${ }^{12}$. Tworzygoemulsja fotograficzna monochromatyczna w sepii naklejona na odwrociu wypukłego szkła oraz naklejone elementy masy perłowej i podmalowanie farbami olejnymi ${ }^{13}$.

Proces tworzenia obrazu wyglądał następująco: odpowiednio przyciętą fotografię ${ }^{14}$ przyklejono błoną fotograficzną do szkła. Usunięto papier fotograficzny i w określonych miejscach (w oknach kamienic) przyklejono małe płatki z masy perłowej. Następnie naniesiono warstwę olejnych farb kryjących. Użyto pastelowych odcieni czerwieni, zieleni, błękitu oraz bieli. Farbę nakładano płasko i swobodnie. W partii nieba błona fotograficzna nie występuje.

Podłoże szklane o wymiarach 13,5 x $18,5 \mathrm{~cm}$ i grubości $1,3 \mathrm{~mm}$ jest wypukłe. Fotografia i warstwa malarska zostały umieszczone od strony wklęśnięcia, licem do szkła. Powierzchnia szkła jest gładka.

Odwrocie obrazu jest osłonięte dwiema tekturami, z których zewnętrzna została przybita do ramy małymi gwoździami. -1424 .

* $\mathrm{Nr}$ inw. Zakładu Konserwacji Malarstwa i Rzeźby Polichromowanej UMK

11 Z. Harasym, Stare fotografie: poradnik kolekcjonera, Warszawa 2005, s. 241.

12 Określenie przyjęte przez Z. Harasyma, ibidem, s. 93.

13 Wykonano badania obrazu metodą Koherentnej Tomografii Optycznej. Badania wykonała mgr Magdalena Iwanicka w Zakładzie Fizyki Medycznej Wydziału Fizyki i Astronomii UMK. Przeprowadzono także badania mikrochemiczne próbek pobranych z warstwy malarskiej, w celu określenia rodzaju użytych pigmentów i spoiwa.

14 Nad górnym konturem architektury występuje „otoczka”, którą tworzy błona fotograficzna, co świadczy o tym, że fotografia została wycięta i następnie naklejona pod szkłem. 
Obraz jest oprawiony w oryginalną drewnianą ramę złoconą szlagmetalem. Pośrodku dolnej listewki ramy znajduje się metalowa tabliczka z napisem: Souvenir aan Amsterdam.

\section{Stan zachowania}

Obraz jest w złym stanie zachowania. Warstwa malarska i emulsja fotograficzna jest odspojona od szkła. Najwięcej ubytków występuje w obrębie nieba - w partii, gdzie nie ma błony fotograficznej.

Przyczyną słabej adhezji warstwy malarskiej do szkła mógł być rodzaj użytego spoiwa $\mathrm{w}$ farbach, które na skutek zmian wilgotności względnej powietrza ulegało pęcznieniom i skurczeniom, jak również brak dostatecznego przeklejenia szkła. Do powstania odspojeń błony fotograficznej od szkła mogła się przyczynić warstwa malarska, znajdująca się na jej odwrociu, która wywoływała naprężenia podczas zmian wilgotności. Na wilgoć mogły również reagować substancje wchodzące w skład błony fotograficznej. Emulsja fotograficzna nieosłonięta warstwą malarską uległa złuszczeniom i ma ubytki.

Tektura osłaniająca odwrocie obrazu jest zakwaszona, osłabiona i zdeformowana. Na jej odwrociu, pośrodku widoczne są ubytki w masie papierowej oraz ciemne plamki świadczące o występowaniu mikroorganizmów. Tektura została wtórnie oklejona taśmą klejącą, gdyż najprawdopodobniej była luźna i nie spełniała funkcji utrzymujących szkło w ramie. Taśma z kolei stworzyła barierę i uniemożliwiała odparowywanie wilgoci wchłanianej przez papier, co przyczyniło się do deformacji papieru i rozwoju mikroorganizmów.

Gwoździe utrzymujące tekturę do ramy skorodowały. Powierzchnia złoceń ramy także skorodowała. Rama natomiast uległa zwichrowaniu i poluzowaniu. Nie spełnia już funkcji utrzymujących obraz.

\section{Wnioski}

Analiza techniki i technologii sześciu obrazów na szkle pozwoliła odkryć różnorodność technik, w jakich zostały wykonane badane obrazy.

Przebadano takie techniki jak witrochromia, pseudowitrochromia, eglomizowanie czy też malowanie „na lustrze”. Oprócz klasycznych technik, dokonano analizy tych mniej znanych, jak crystoleum. 
W większości obrazów dobór szklanych podobrazi przez artystów był przypadkowy. Grubość szkła różniła się od 1,2 mm do $4 \mathrm{~mm}$. Było to uzależnione od sposobów produkcji - ręcznego dmuchania, bądź maszynowego wytwarzania. Jedynie jeśli chodzi o obrazy wykonane w technice crystoleum, w trakcie wytwarzania były one specjalnie formowane, aby uzyskać wypukłą powierzchnię charakterystyczną dla tej techniki (Widok Amsterdamu - kamienice).

Wśród użytych przez artystów środków wypowiedzi artystycznej najczęściej stosowane były farby o spoiwie olejnym i emulsyjnym, płatki złota, srebra i szlagmetalu, amalgamat, brąza, litografie i drzeworyty, reprodukcje oraz fotografia. Zaobserwowano również występowanie żywicznej warstwy zabezpieczającej, którą nakładano na odwrocie obrazu (Pejzaż).

Przeprowadzone badania stanu zachowania obrazów pozwoliły odpowiedzieć na pytanie, co jest główną przyczyną powstawania zniszczeń. Stan zachowania większości obiektów jest zły. Zniszczenia, takie jak pęknięcia i ubytki podobrazia szklanego, powstawały najczęściej na skutek uderzeń mechanicznych.

Można zaobserwować także odspojenia i ubytki warstwy malarskiej, złoceń i amalgamatu.

Głównej przyczyny utraty przyczepności warstwy malarskiej do szkła należy dopatrywać się w błędach technologicznych i technicznych budowy obiektów, jak i przede wszystkim w nieprawidłowych warunkach ich przechowywania. Stwierdzono występowanie zależności między budową technologiczną obrazów a ich niszczeniem. Poszczególne warstwy przeklejenia i farby mają inną wrażliwość na wilgoć i wodę kondensacyjną, która w niekorzystnych warunkach mikroklimatycznych bardzo często skrapla się na odwrociu nieprzepuszczalnego dla pary wodnej szkła. Świadczą o tym zniszczenia występujące w postaci ubytków i spęcherzeń warstwy malarskiej, głównie w dolnych partiach obrazu. Oddziaływanie pary wodnej może się zintensyfikować, kiedy obraz jest powieszony na zimnej zewnętrznej ścianie.

Niewątpliwie na utratę przyczepności warstwy malarskiej do szkła ma również wpływ miękka, tekturowa czy papierowa, osłona odwrocia. Są to materiały higroskopijne, które należy uznać za nieod- 
powiednie, ponieważ działają jak akumulatory pary wodnej wzmacniające efekty spowodowane wzrostem wilgotności. Zalecane jest stosowanie drewnianej osłony odwrocia, która w dużym stopniu niweluje skutki skoków wilgotności i temperatury otoczenia. Jednakże drewniane osłony odwrocia i ramy bardzo często są atakowane przez owady. Przyczynia się to do wypaczenia, poluzowania konstrukcji i w konsekwencji ma wpływ na zniszczenia w warstwie malarskiej. Natomiast, jeśli chodzi o papierowe osłony, to ulegają one zakwaszeniu, co również może zaszkodzić warstwie malarskiej, a także spowodować korozję folii srebrnych.

Niekorzystne warunki mikroklimatyczne mogą przyczynić się do rozwoju mikroorganizmów. Niektóre kolonie zaplamiają warstwy barwne, co wpływa na nieczytelność obrazu. Rozłożone przez mikroorganizmy spoiwa w przeklejeniu i warstwie malarskiej powodują odspojenia, pudrowanie i osypywanie warstw farby.

Między warstwą malarską a szkłem gromadzi się kurz i pyły, których usunięcie jest bardzo utrudnione. Problem ten dotyczy większości badanych obrazów. Brak przeklejenia szkła może mieć wpływ na utratę adhezji warstwy malarskiej do szkła - co zauważono na przykładzie obrazu Widok Amsterdamu - kamienice. W nieprzeklejonej partii tła było najwięcej odspojeń i ubytków.

Złożoność problemów konserwatorskich dotyczących obrazów na szkle decyduje o tym, że te obiekty są rzadko konserwowane. Wśród badanych obrazów tylko jeden był konserwowany - Martwa natura - Vanitas, natomiast większość była poddana naprawom wykonanym przez niekompetentne osoby, co wywołało dalsze zniszczenia.

Decyzja o kolejności i zakresie działań konserwatorskich musi być poprzedzona wnikliwą analizą budowy technicznej i stanu zachowania obrazu. Brak odpowiedniego programu i analiz może grozić całkowitym zniszczeniem tak cennych obiektów, jakimi są obrazy na szkle. Oprócz prac konserwatorsko-restauratorskich należy brać także pod uwagę wszystkie działania ochronne i sposoby hamowania przebiegu procesów destrukcji. Chodzi tu głównie o poprawę warunków eksponowania oraz magazynowania obiektów, a także o korektę klimatu we wnętrzu. 


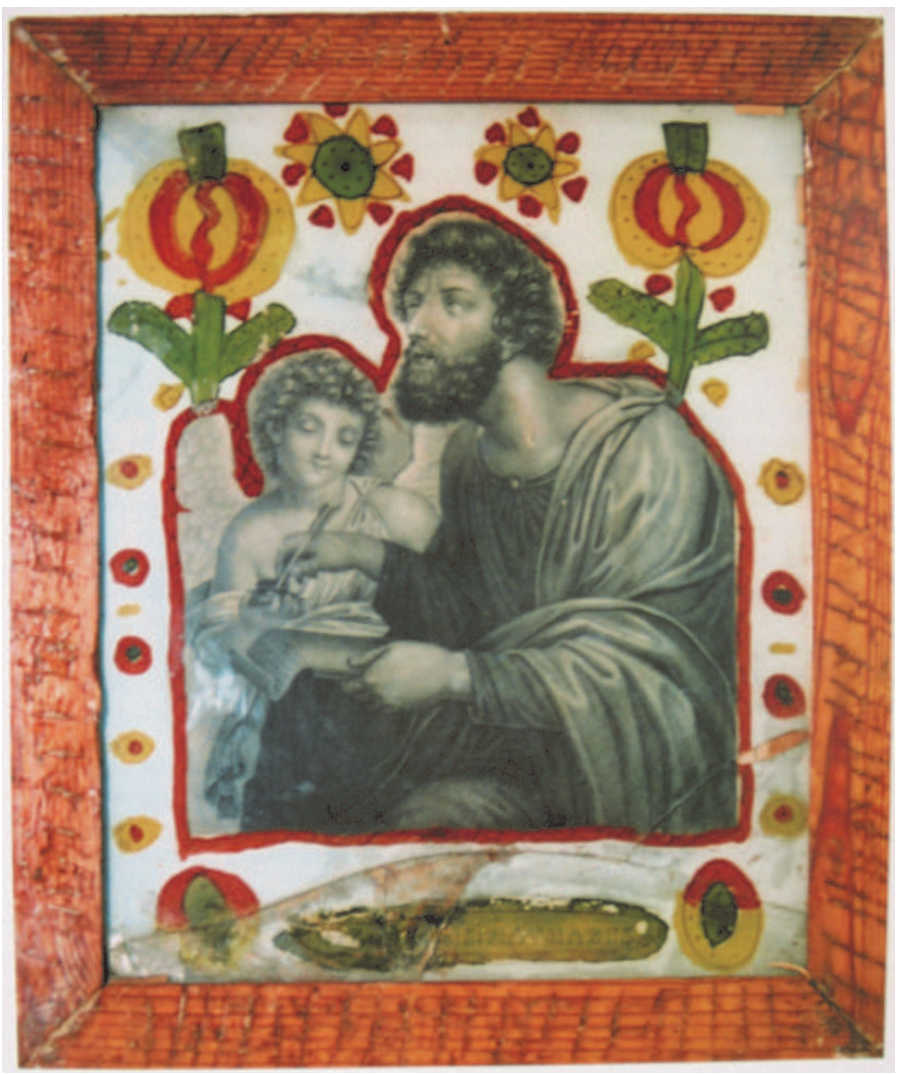

Fot. 1. Św. Mateusz, zdjęcie lica obrazu z ramą (A. Błachowski, Malarstwo na szkle, Lublin-Toruń 2004, s. 151)

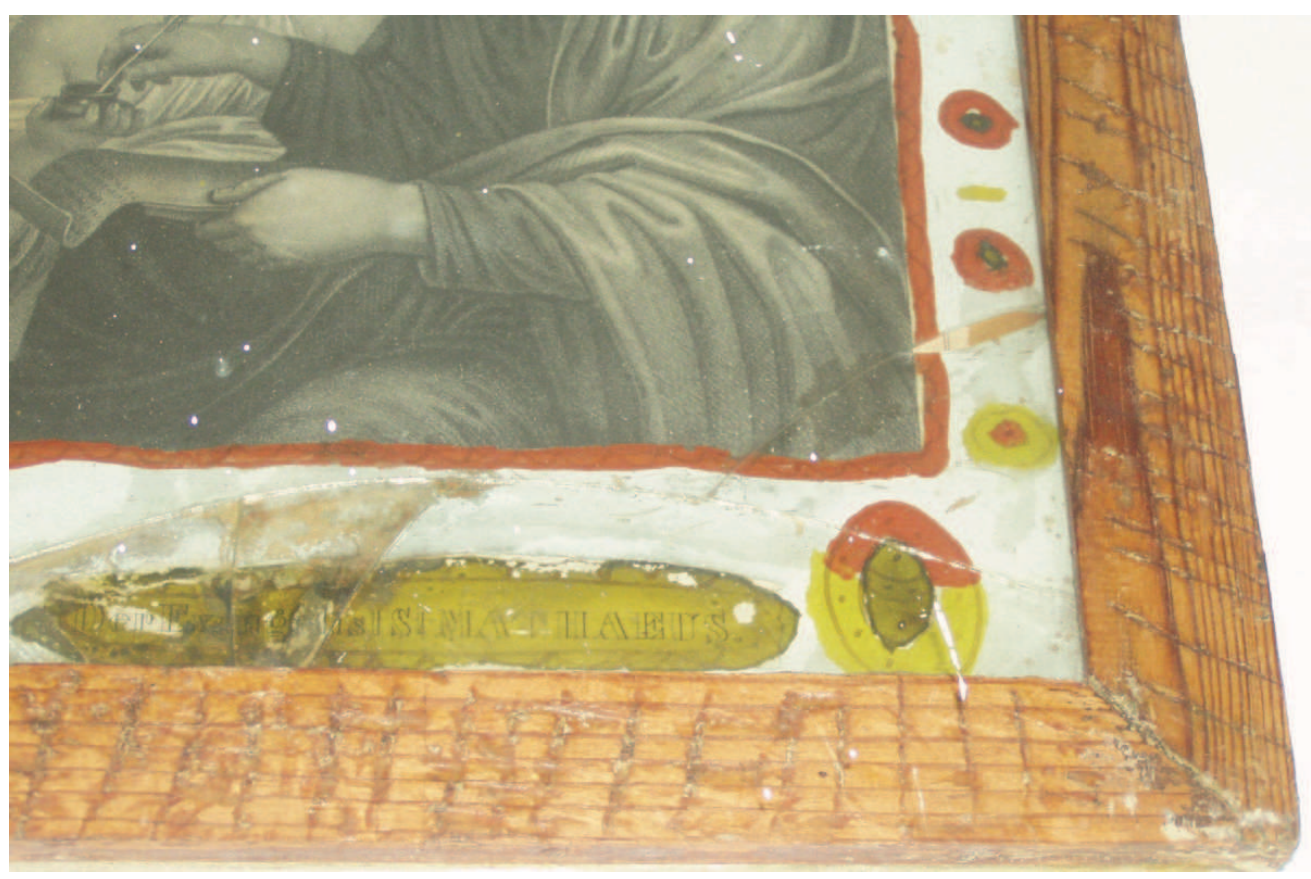

Fot. 2. Fragment obrazu Św. Mateusz; widoczne zniszczenia warstwy malarskiej spowodowane nieumiejętnie przeprowadzonym klejeniem fragmentów pękniętego podobrazia (fot. B. Szmelter-Fausek) 


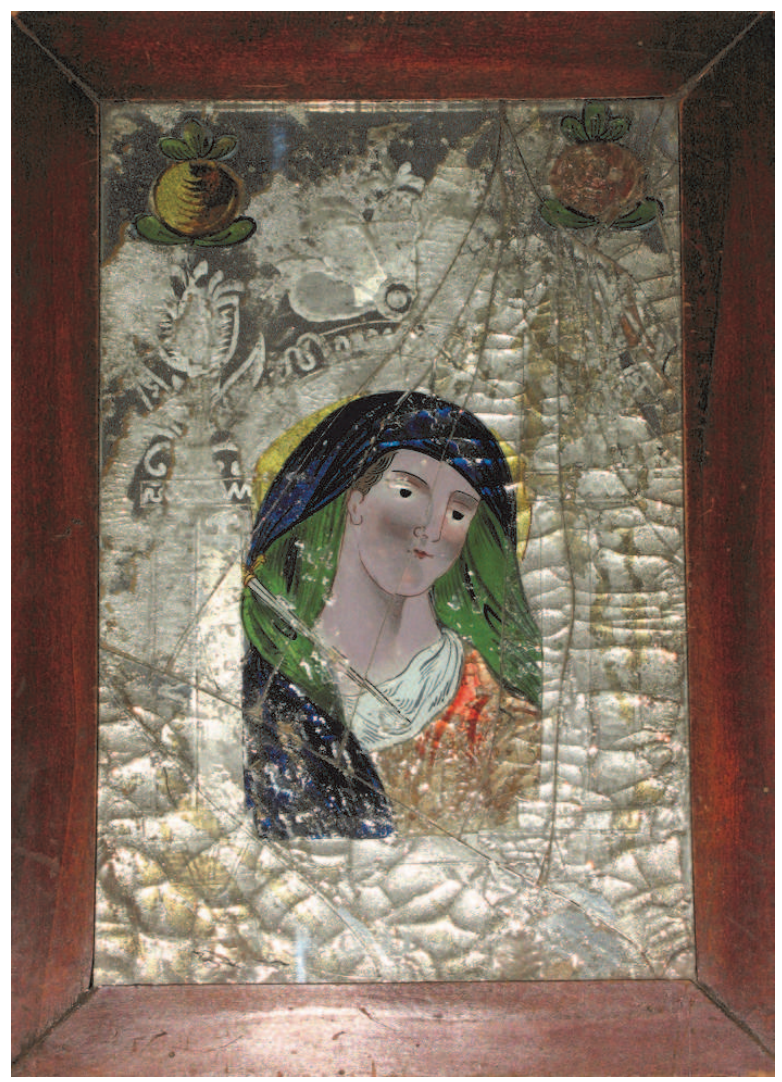

Fot. 3. Matka Boska Bolesna, lico obrazu w ramie (fot. B. Szmelter-Fausek)

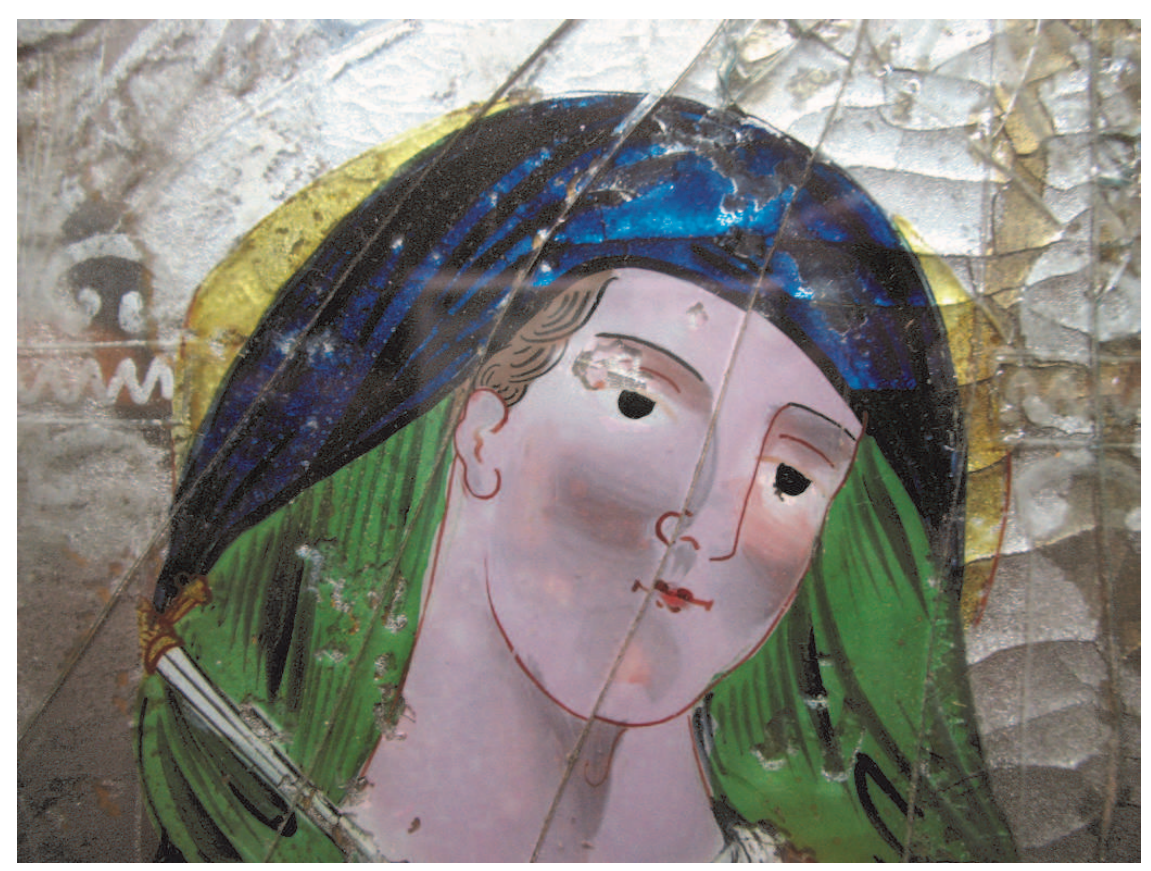

Fot. 4. Fragment obrazu Matka Boska Bolesna; widoczne pęknięcia szkła, odspojenia warstwy malarskiej i amalgamatu (fot. B. Szmelter-Fausek) 


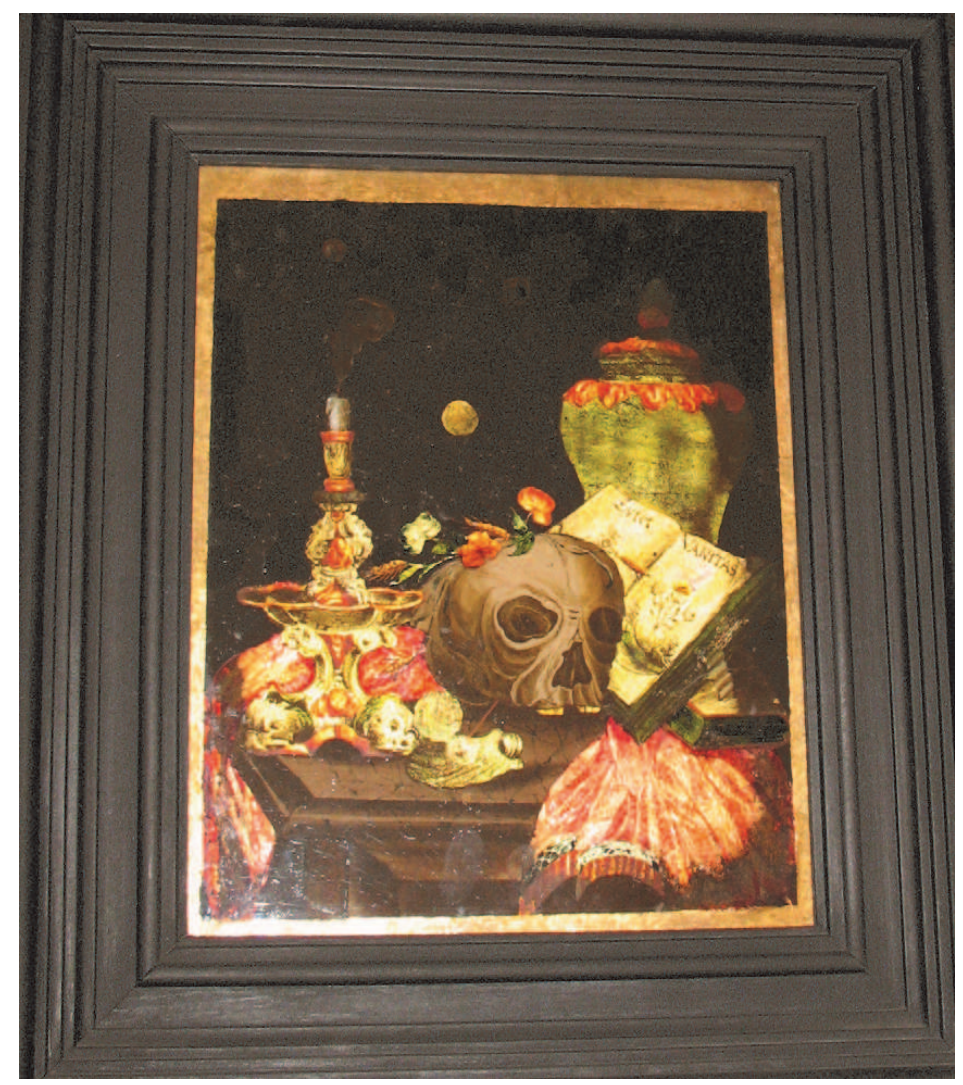

Fot. 5. Martwa natura - Vanitas, lico obrazu z ramą (fot. B. Szmelter-Fausek)

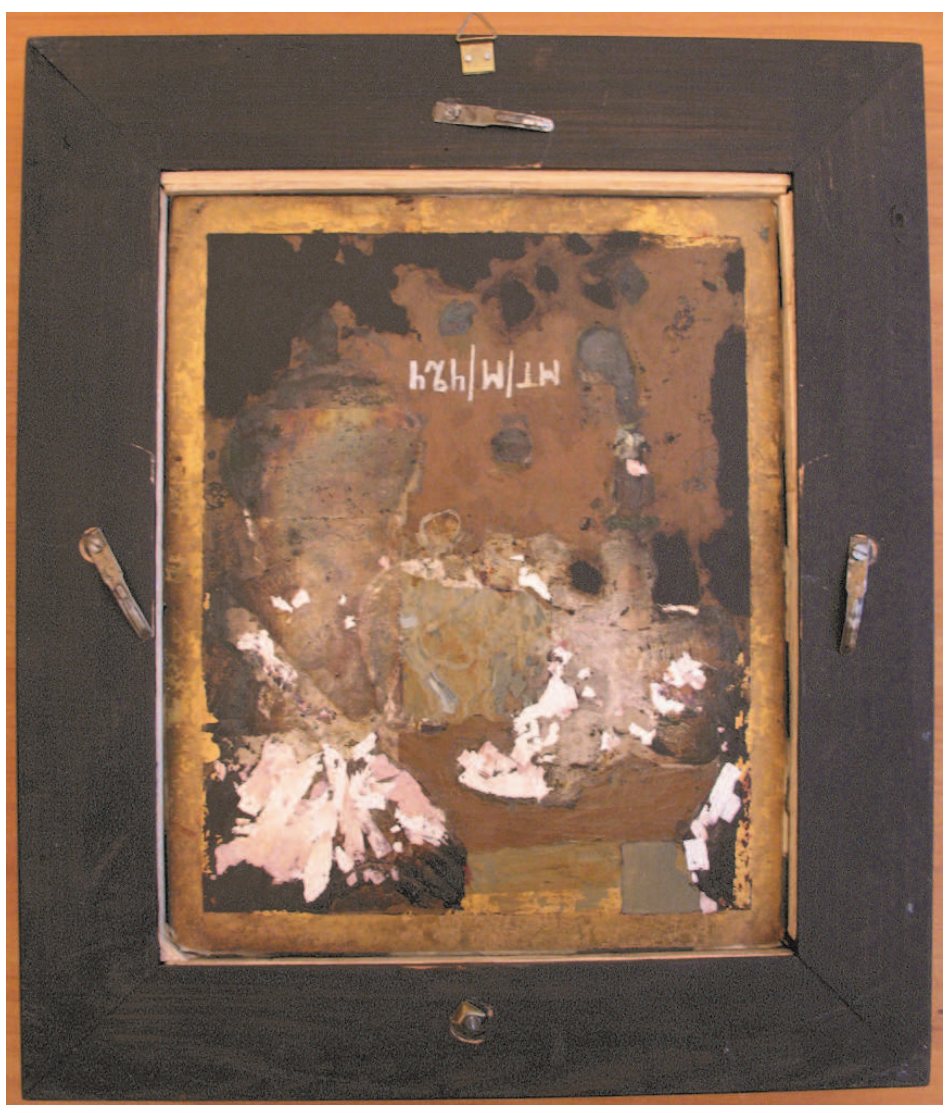

Fot. 6. Martwa natura Vanitas, odwrocie obrazu $\mathrm{z}$ ramą (fot. B. Szmelter-Fausek) 


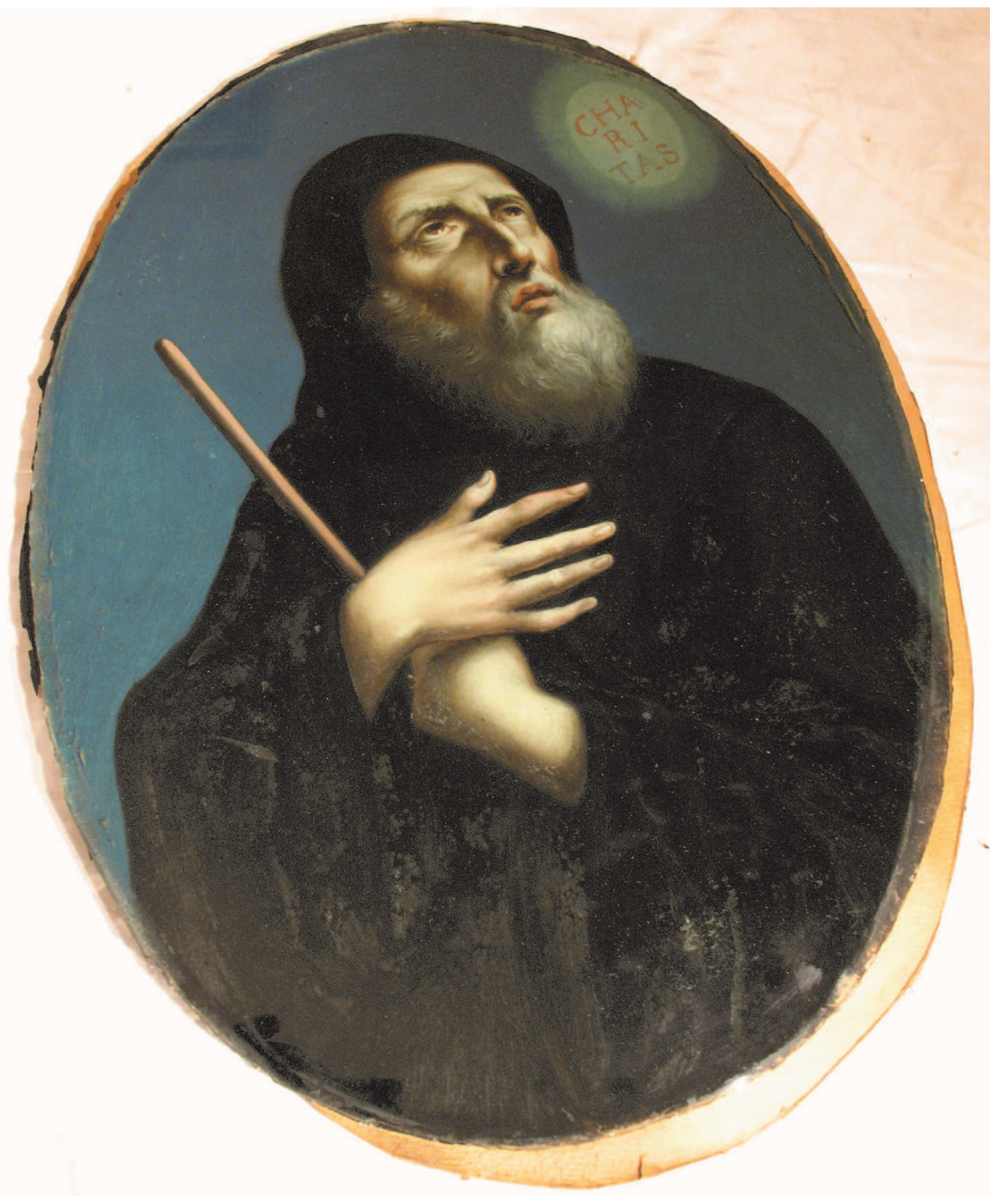

Fot. 7. Św. Wincenty à Paulo, lico obrazu (fot. B. Szmelter-Fausek) 


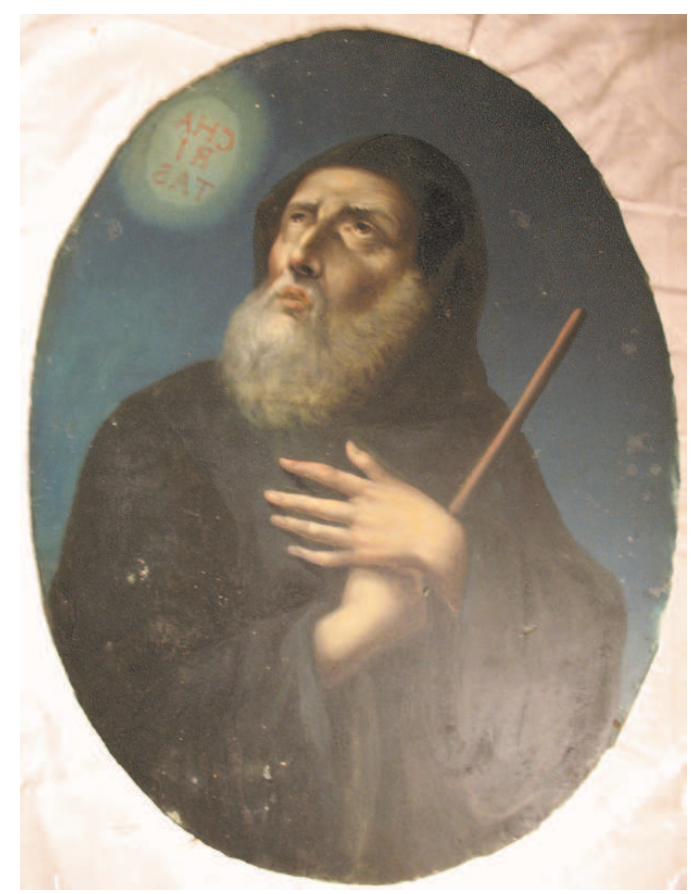

Fot. 8. Św. Wincenty à Paulo, odwrocie obrazu (fot. B. Szmelter-Fausek)

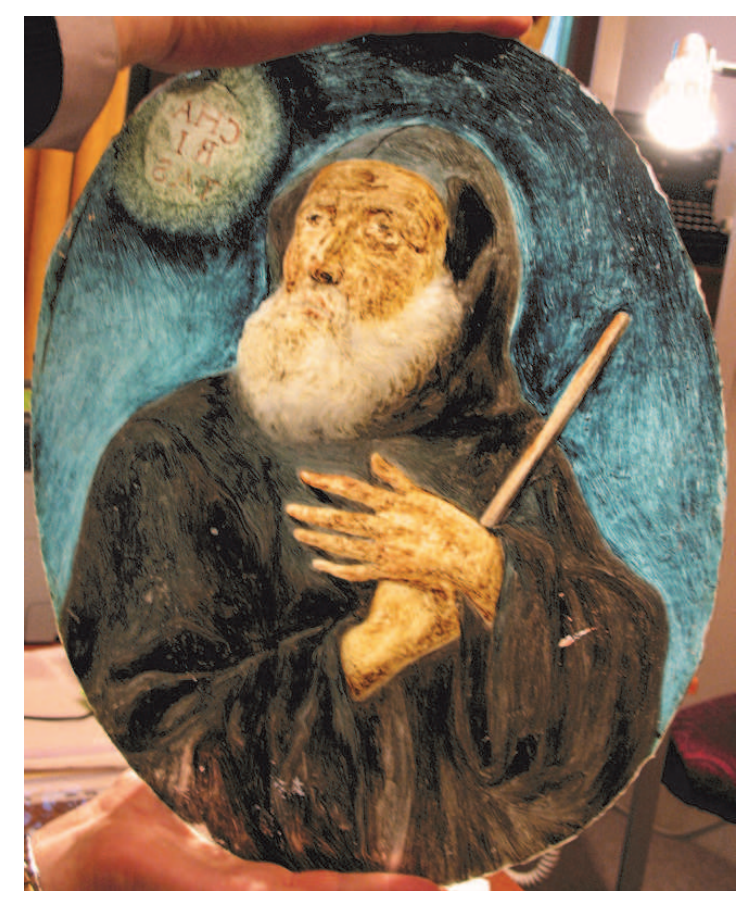

Fot. 9. Św. Wincenty à Paulo, odwrocie obrazu w świetle przechodzącym (fot. B. Szmelter-Fausek)

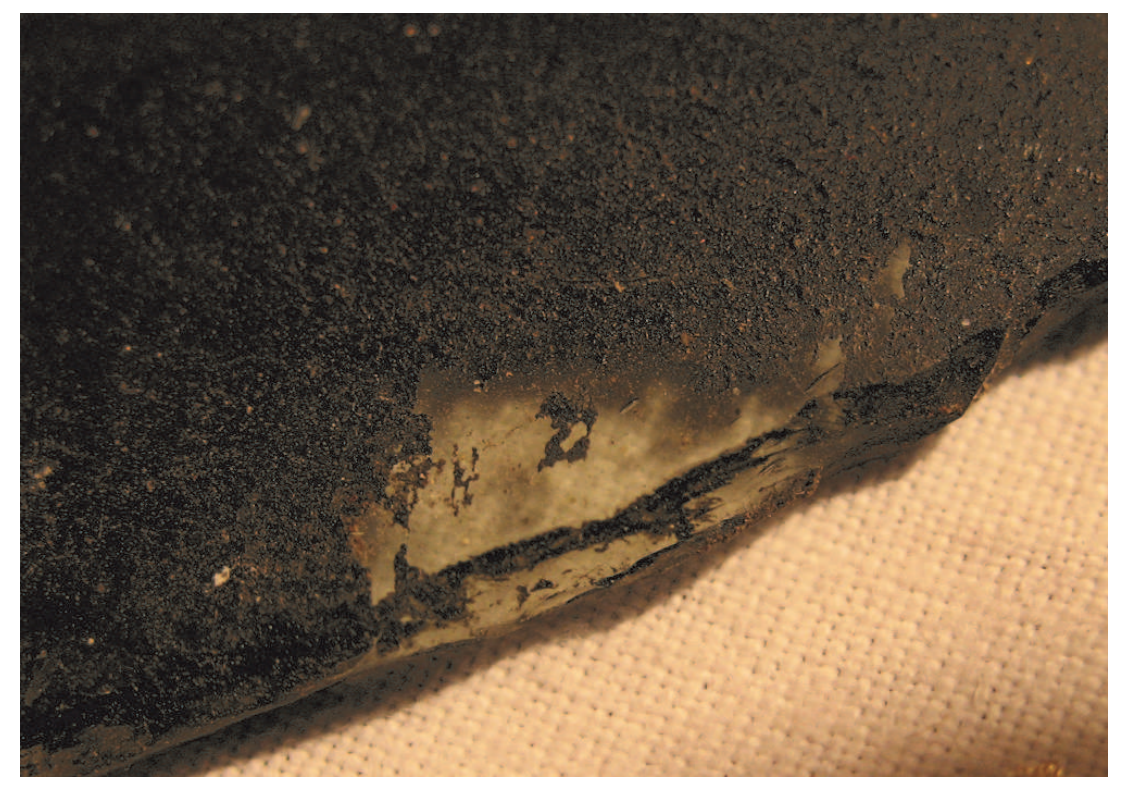

Fot. 10. Fragment odwrocia obrazu Św. Wincenty à Paulo; widoczny sposób wycięcia szyby oraz ubytek warstwy malarskiej (fot. B. Szmelter-Fausek) 


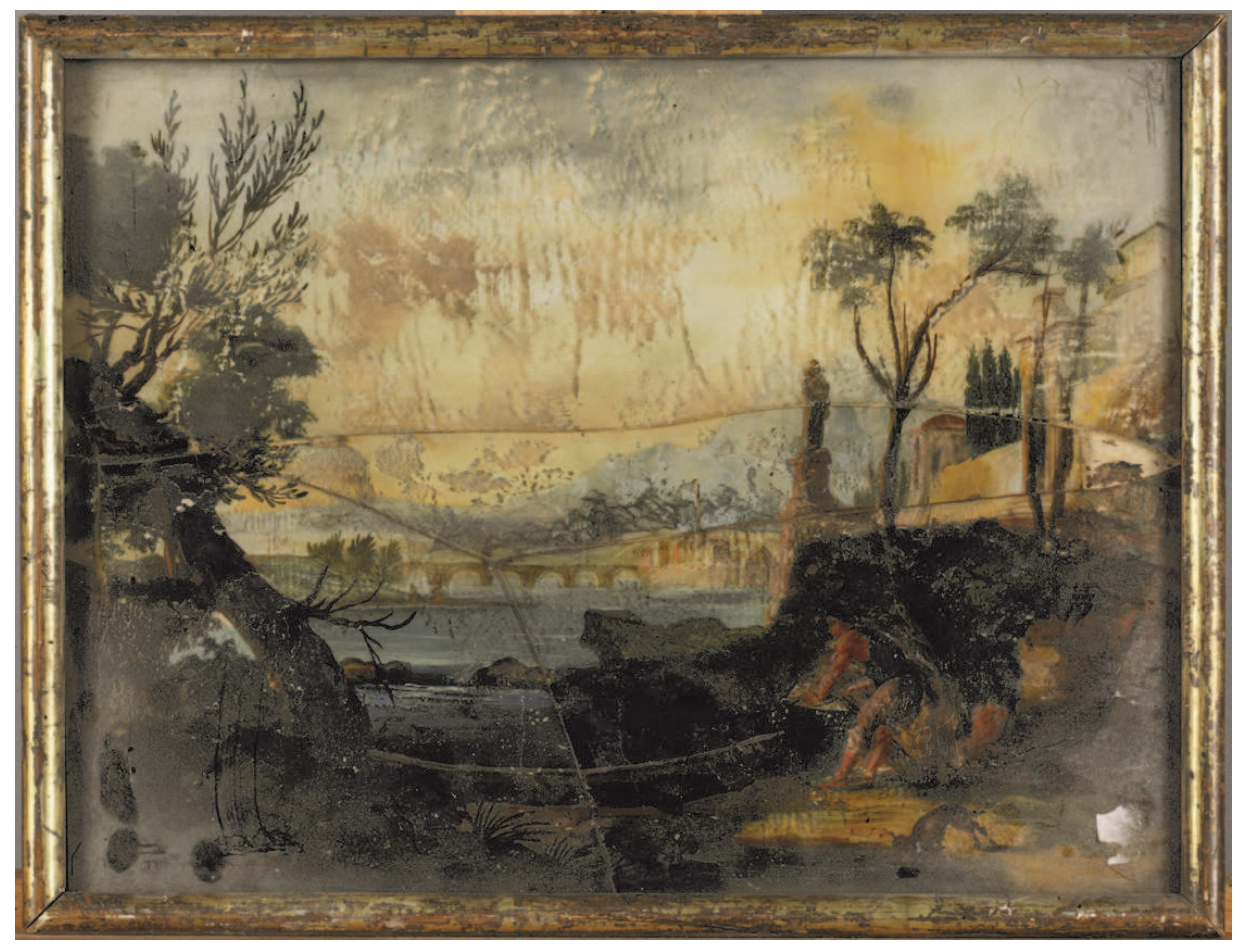

Fot. 11. Pejzaż, lico obrazu z ramą (fot. B. Szmelter-Fausek)

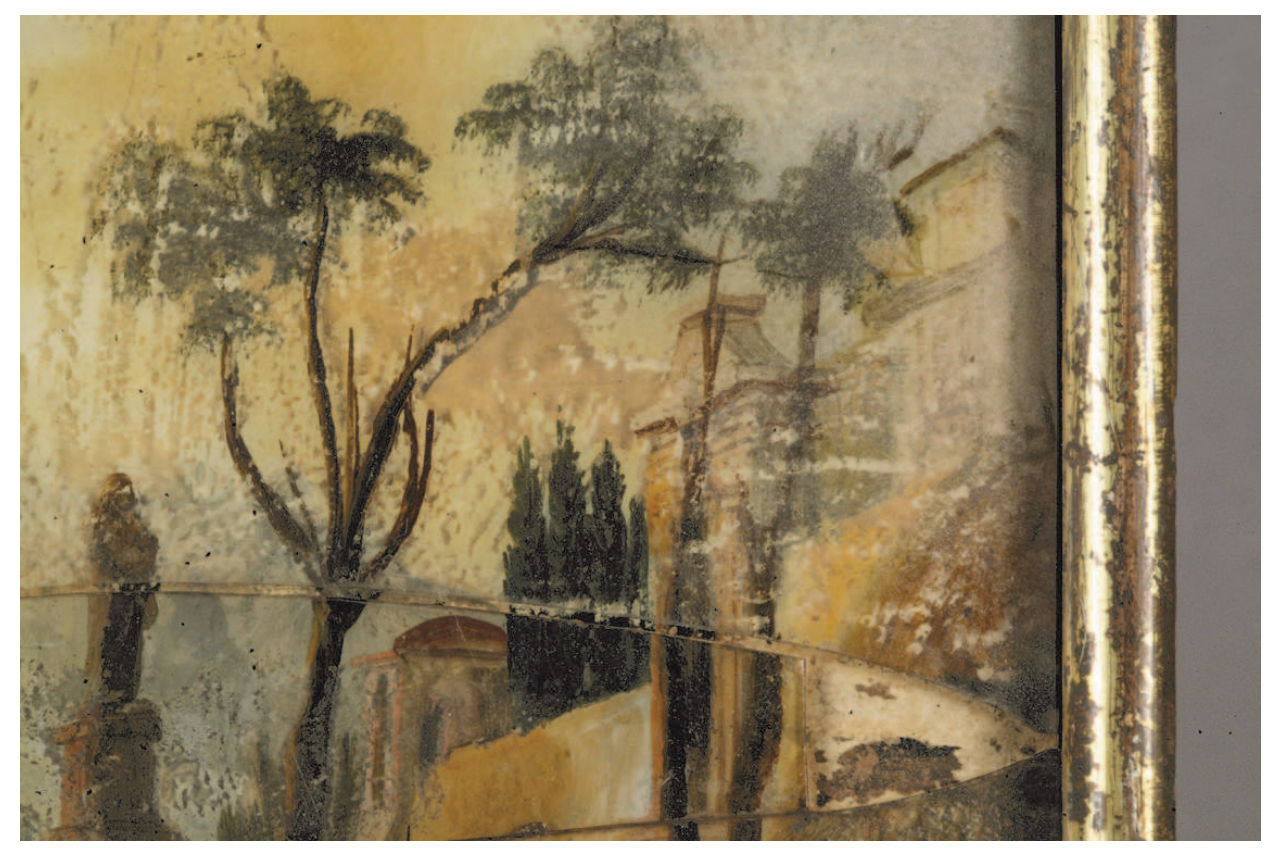

Fot. 12. Fragment obrazu Pejzaż; widoczne odspojenia warstwy malarskiej zerwanej przez tekturę znajdującą się za obrazem oraz ubytek szkła (fot. B. Szmelter-Fausek) 


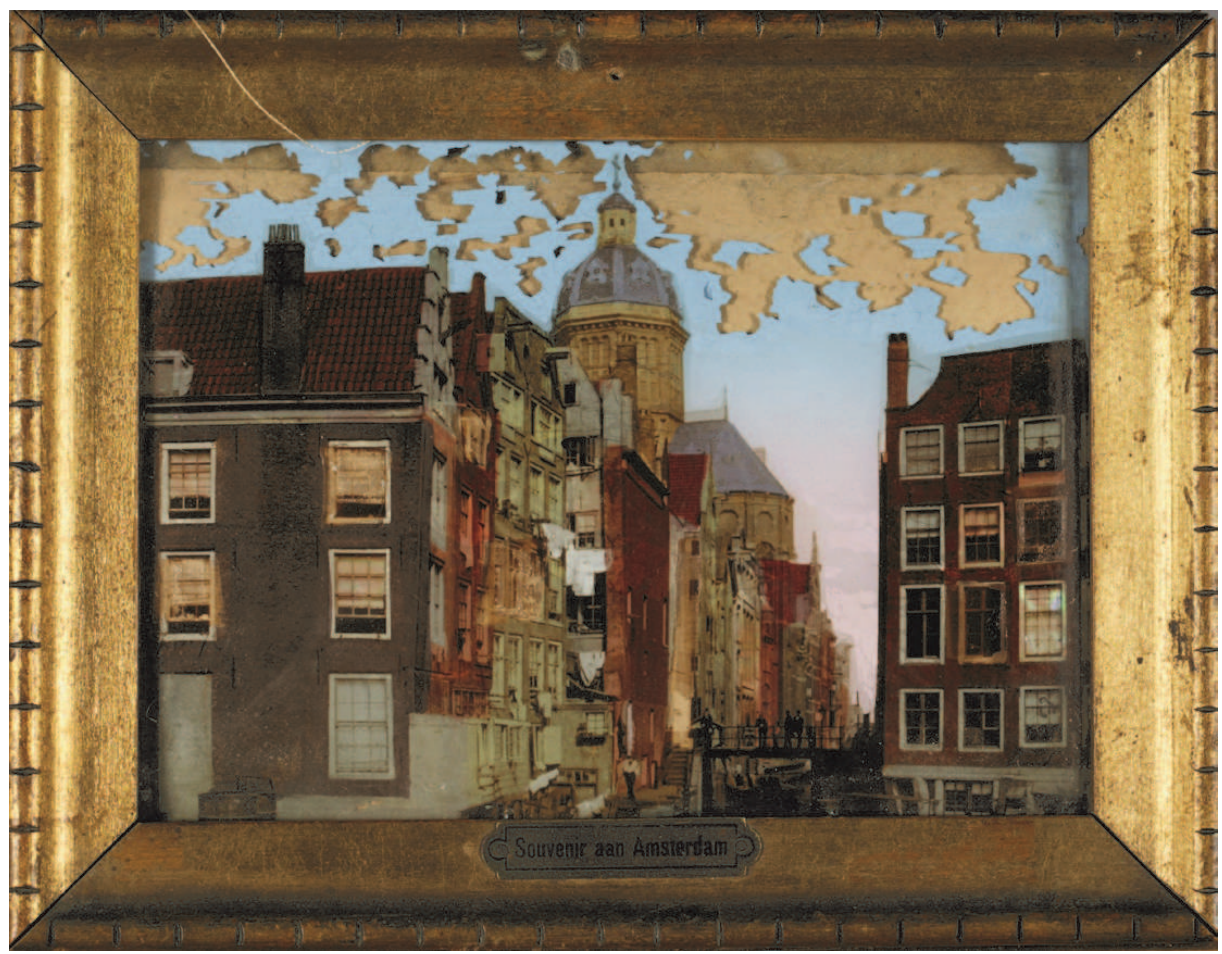

Fot. 13. Widok Amsterdamu - kamienice, lico obrazu z ramą (fot. B. Szmelter-Fausek)

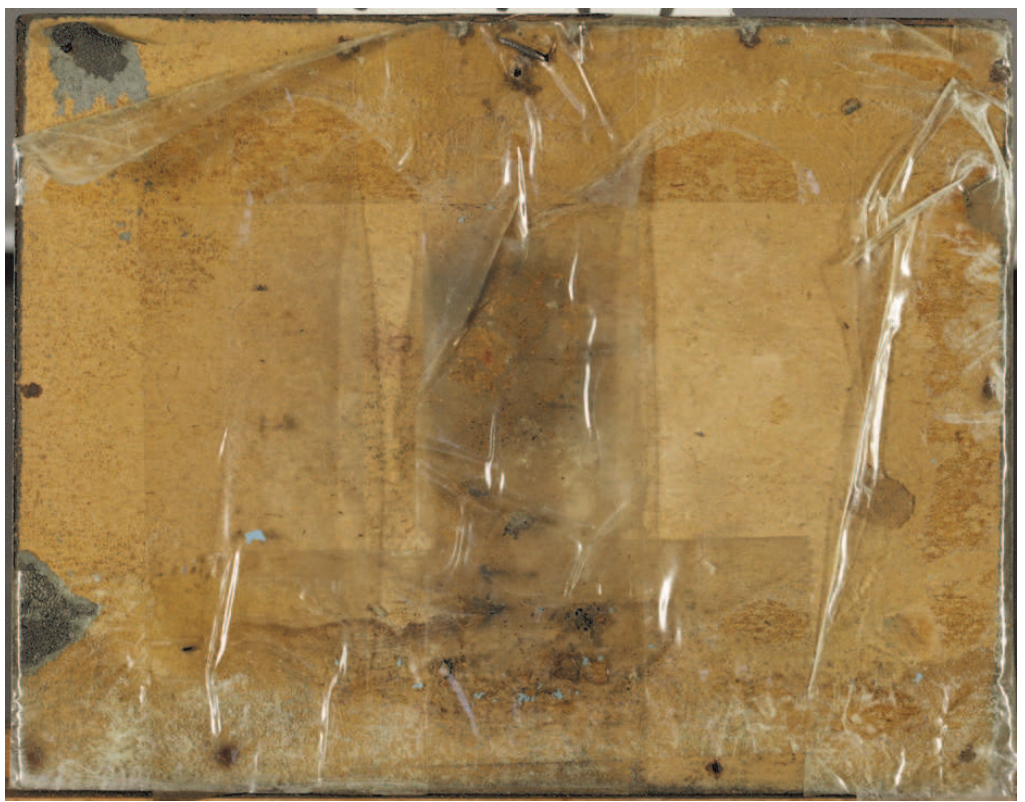

Fot. 14. Widok Amsterdamu - kamienice, osłona obrazu; widoczne zniszczenia powstałe na skutek oklejenia odwrocia taśmą klejącą (fot. B. Szmelter-Fausek) 


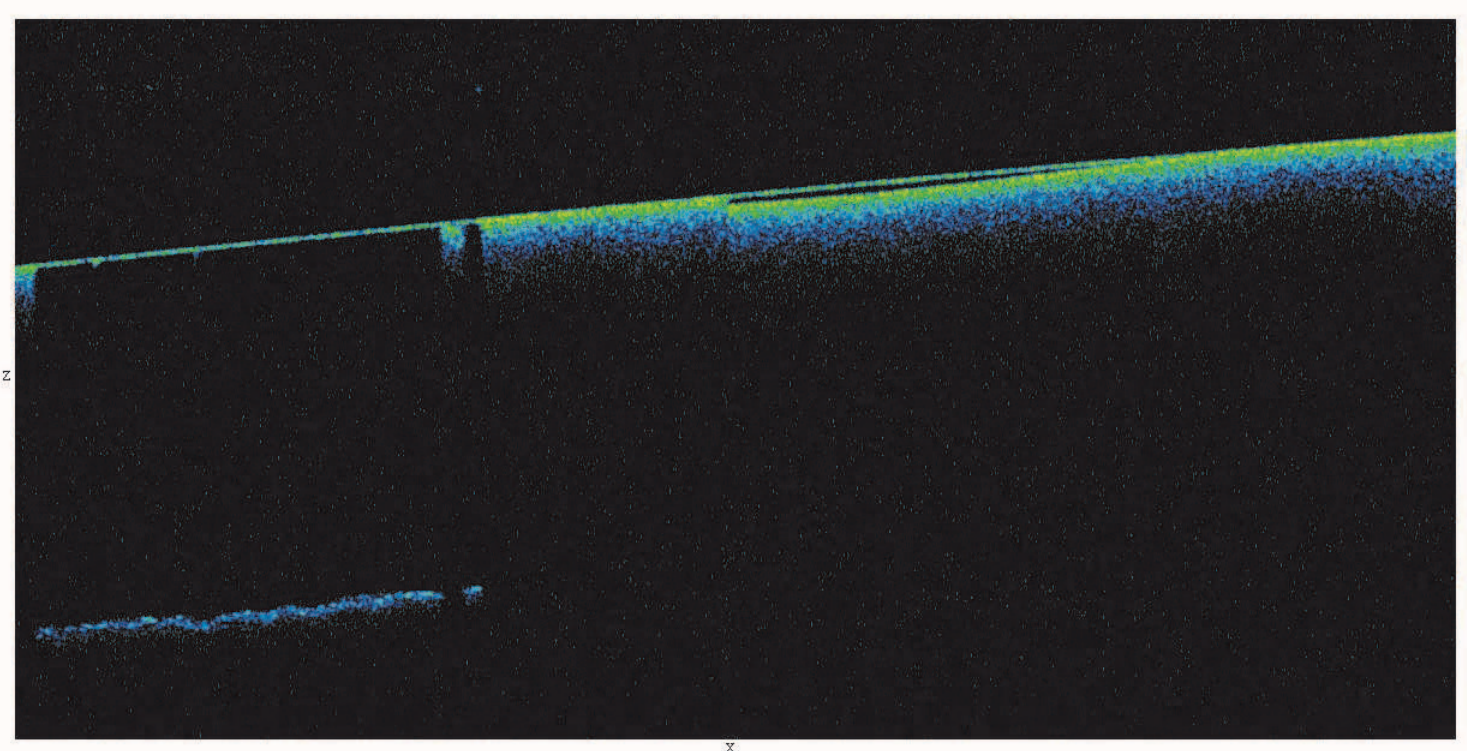

$\sqrt{200} \mathrm{um}$

Obiekt:

obraz na szkle_1424_16 kwietnia

( $\mathrm{X}: 0,0 \mathrm{~cm} / \overline{\mathrm{Y}}: 0,0 \mathrm{~cm}$ )

T: $23,6 \operatorname{deg}$ C / RH: $37,9 \%$

Pomiar:

16-04-2008 ( 11:53:46)

Pojedynczy pomiar

Opis:

technika wykonania obrazu, od strony lica: szyba, żel atyna, emulsja z odbitki fotograficznej, (wosk?), wars twa mal.

obszar pomiarowy: wnętrze szkla - granica z warstwam i technol. obrazu; skany pionowe w obszarze odspojen i ubytku warstwy malarskiej
Wymiar $(\mathrm{X}|\mathrm{Y}| \mathrm{Z})[\mathrm{mm}]$ : $7,0|8,0| 2,58$

Tomogram:

$16 / 150$
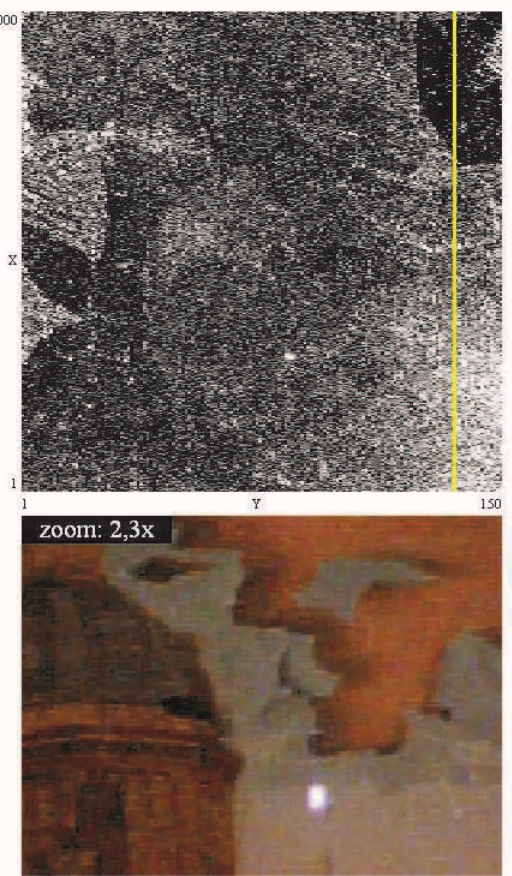

b)

c)

Fot. 15. Widok Amsterdamu - kamienice, wynik badania OCT: a) tomogram OCT - przekrój stratygraficzny; po prawej stronie widoczne jest odspojenie warstwy emulsji fotograficznej z warstwą malarską od szkła, po lewej stronie - ubytek warstw barwnych, u dołu widoczny karton osłaniający odwrocie obrazu; b) widok miejsca badania (reflektogram w podczerwieni, na długości fali używanej w badaniu, linia żółta pokazuje lokalizację tomogramu); c) widok miejsca w świetle rozproszonym 


\section{Summary}

\section{Reverse painting on glass - research on technique and preservation state}

There are research on technique and preservation state presented in the article. The reasons of damages were defined on the example of six reverse painting on glass from The Museum in Kartuzy, The Ethnographic Museum in Toruń, The Regional Museum in Toruń, The Diocesan Museum in Włocławek and from the private collection.

The reverse painting on glass represent different techniques: english painting behind glass (franc. fixé sous verre, niem. Die Englische Malerei hinter Glass, pol. pseudowitrochromia), mirror painting on glass, reverse painting on glass (franc. peinture sous verre, niem. Hinterglasmalerei, pol. witrochromia), reverse foil engraving (franc. verre églomisé, niem. Eglomisieren) and crystoleum.

Preservation state of majority of the paintings is bad. The research gave the answer what is the main reason of the damages. Broken and loosen glass is caused mainly by the mechanical treatment.

There is failure of adhesion between the paint and the glass and loss of the paint layer, of the gold and of the amalgam.

The technical mistakes during the process of the production of paintings and the bad storage condition is the main reason of failure of adhesion between the paint and the glass. 